\begin{tabular}{l|l}
\hline Cotaice & $\begin{array}{l}\text { e-ISSN: 2655-9404 p-ISSN: 2721-8376 } \\
\text { DOI: } 10.20473 / \text { ntr.v4i2.26119 }\end{array}$ \\
Vol. 4 No. 2, Juni 2021 &
\end{tabular}

Article history: Submitted 27 March 2021; Accepted 2 April 2021; Available online 1 June 2021.

\title{
Jual Beli Tanah Dalam Hukum Tanah Atas Akta Perjanjian Pengikatan Jual Beli Bertingkat yang Dibuat oleh Notaris
}

\author{
Nailu Vina Amalia \\ Nailuvaa@gmail.com \\ Universitas Airlangga
}

\begin{abstract}
The deed of the purchase and sale agreement (PPJB). The deed of the sale and purchase agreement is a preliminary agreement prior to the sale and purchase of land. PPJB is used only once. If what is agreed in the PPJB has been fulfilled then the signing of the sale and purchase deed can be carried out, by signing the sale and purchase deed, the ownership of land rights has been transferred. There are still many people who think that when the PPJB is signed, there will be a transfer of land rights, even though the PPJB is not an evidence of a transfer of land rights. This thesis discusses graded PPJB or recurring PPJB made by a Notary on a plot of land based on ownership rights over land use rights of former customary land based on the quotation of the Decree of the Governor of East Java Region Serial Number I/Agr/117 XI/HM/01.G/1970 issued November 4, 1970, or uncertified land. Whether it contradicts the concept of buying and selling in agrarian law and the legal consequences of the PPAT who made the sale and purchase deed based on the graded PPJB. Keywords: Graded PPJB; Recurring PPJB: Proof of Prior Rights.
\end{abstract}

\begin{tabular}{l}
\hline Abstrak \\
\hline Akta Perjanjian Pengikatan Jual Beli (akta PPJB). Akta PPJB merupakan perjanjian \\
pendahuluan sebelum diadakannya jual beli tanah. Akta PPJB digunakan untuk \\
sekali saja, namun prakteknya masih ditemukan Akta PPJB bertingkat. Masih banyak \\
masyarakat yang menganggap apabila sudah ada akta PPJB sudah ada peralihan hak \\
atas tanah, padahal akta PPJB bukan bukti adanya peralihan hak atas tanah. Akta Jual \\
Beli (AJB) yang merupakan bukti adanya peralihan hak atas tanah. AJB dibuat apabila \\
syarat-syarat yang ada dalam akta PPJB sudah terpenuhi. Dalam tesis ini membahas \\
tentang akta PPJB bertingkat atau akta PPJB berulang yang dibuat oleh Notaris atas \\
sebidang tanah berdasarkan Hak Milik atas tanah Hak Pakai bekas Gogolan tidak tetap \\
berdasarkan Kutipan Surat Keputusan Gubernur Kepala Daerah Tingkat I Jawa Timur \\
Nomor I/Agr/117/XI/HM/01.G/1970 tertanggal 4 Nopember tahun 1970 atau tanah \\
yang belum bersertipikat apakah akta PPJB bertingkat tersebut bertentangan dengan \\
konsep jual beli dalam hukum tanah dan akibat hukum dari Pejabat Pembuat Akta Tanah \\
(PPAT) membuat AJB berdasarkan akta PPJB bertingkat.
\end{tabular}
Kata Kunci: PPJB Bertingkat; PPJB Berulang; Bukti Hak Lama.

\section{Pendahuluan}

Copyright (C) 2021 Nailu Vina Amalia. Published in Notaire. Published by Universitas Airlangga, Magister Kenotariatan.

Jual beli tanah dalam hukum tanah haruslah memenuhi syarat-syarat sah dari jual beli tersebut. Syarat-syarat jual beli terdiri dari syarat materiil dan syarat formil. Syarat materiil ini berhubungan dengan subjek pemegang hak atas tanah, yang mana penjual dan pembeli harus merupakan subjek yang dapat menjadi 
pemegang hak atas tanah. Syarat formil ini berkaitan dengan pendaftaran tanah, dalam jual beli tanah harus dibuktikan dengan menggunakan akta yang dibuat oleh Pejabat Pembuat Akta Tanah yang selanjutnya disebut dengan PPAT sebagaimana diatur dalam Pasal 37 ayat (1) Peraturan Pemerintah Nomor 24 Tahun 1997 Tentang Pendaftaran Tanah yang selanjutnya disebut dengan PP 27/1997. Selain ada syarat materiil dan formil dalam jual beli tanah juga harus memenuhi syarat sah jual beli menurut hukum adat. Syarat sahnya jual beli hak atas tanah menurut hukum adat adalah terpenuhinya tiga unsur yaitu tunai, riil dan terang. ${ }^{1}$ Tunai adalah adanya pembayaran secara tunai dan juga bisa sebagian, riil adalah adanya kesepakatan dan juga adanya penyerahan secara nyata. Terang memiliki pengertian bahwa jual beli harus dihadapan pejabat yang berwenang, pada saat masih berlakunya Peraturan Pemerintah Nomor 10 Tahun 1961 Tentang Pendaftaran Tanah yang selanjutnya disebut dengan PP 10/1961, pejabat yang berwenang adalah kepala desa, sehingga dalam melakukan jual beli harus dihadapan kepala desa. Setelah PP 10/1961 tidak berlaku pejabat berwenang ini adalah PPAT sebagaimana yang diatur dalam PP 24/1997.

Bukti telah terjadinya jual beli dibuktikan dengan syarat formil yaitu adanya akta jual beli yang selanjutnya disebut dengan AJB. AJB merupakan akta otentik yang dibuat oleh PPAT. Jika dokumen-dokumen dalam jual beli serta sudah lunasnya pembayaran dapat langsung diadakannya tandatangan AJB dihadapan PPAT. Jika dokumen-dokumen dalam jual beli belum lengkap dapat mengadakan perjanjian pendahuluan yaitu akta perjanjian pengikatan jual beli. Menurut R. Subekti akta PPJB merupakan perjanjian antara penjual dan pembeli sebelum dilaksanakannya jual beli, hal itu dikarenakan terdapat unsur-unsur yang harus dipenuhi dalam jual beli. ${ }^{2}$ Unsur tersebut misalnya tanah yang belum bersertipikat yang harus didaftarkan terlebih dahulu ke Kantor Pertanahan Kabupaten/Kota atau bisa juga belum lunasnya pembayaran dan pajak-pajak yang harus dibayarkan penjual dan pembeli.

\footnotetext{
${ }^{1}$ Maria S. W. Sumarjono, Kebijakan Pertanahan antara Regulasi dan Implementasi (Buku Kompas 2001).[119].

${ }^{2}$ R. Subekti, Hukum Perjanjian (Bina Cipta 1987).[75].
} 
Akta PPJB terdiri dari dua jenis, Akta PPJB lunas yang selalu bertalian dengan akta kuasa menjual da nada akta PPJB belum lunas. Hingga saat ini masih ada yang menganggap bahwa dengan ditandatanganinya PPJB sudah terjadi peralihan hak atas tanah, padahal akta PPJB bukan merupakan bukti adanya peralihan hak atas tanah. Ketidaktahuan tersebut menyebabkan pembeli yang masih tahap PPJB menjual tanah ke pihak ketiga karena menganggap bahwa adanya akta PPJB tanah sudah beralih ke pembeli. Pada dasarnya akta PPJB digunakan hanya sekali untuk melakukan AJB namun prakteknya ada PPJB yang di PPJB-kan berulang atau PPJB bertingkat. Salah satu kasus PPJB bertingkat ini, yaitu di Sidoarjo. Tahun 1994 tuan Sarbilin menjual tanahnya yaitu tanah hak milik berdasarkan Surat Keputusan Gubernur Kepala Daerah Tingkat I Jawa Timur Nomor I/ Agr/117/ XI/HM/01.G/1970 tertanggal 4 Nopember tahun 1970 yang selanjutnya disebut SK Gubernur dengan nomor petok 465 kepada nyonya Demi. Tuan Sarbilin dan nyonya Demi bersepakat untuk membuat akta PPJB dan akta kuasa dengan nomor akta 44 dan 45 pada tanggal 14 Januari 1994. Pada tahun 1997 tuan Soeradi menjual tanah hak milik berdasarkan SK Gubernur dengan nomor petok 466 kepada tuan Suwardi dan juga bersepakat membuat akta PPJB dan akta kuasa di Notaris dengan nomor akta 44 dan 45 tanggal 8 Januari 1997. Ditahun 2012 nyonya Satun dan tuan Ngatimir menjual tanah hak milik berdasarkan SK Gubernur dengan nomor petok 425 dan 262 kepada tuan MAA. Ditahun dan ditanggal yang sama yaitu tanggal 31 Mei 2012 nyonya Demi dan tuan Suwardi menjual tanah berdasarkan SK Gubernur tersebut ke tuan MAA, belum ada peralihan hak atas tanah dan juga tanah belum didaftarkan di Kantor Pertanahan Kabupaten/Kota tuan MAA menjual tanah tersebut ke tuan Samsu. Jika dilihat akta PPJB dari tahun 1994 dan tahun 1994 sudah menjadi akta PPJB bertingkat dua sedangkan untuk tanah milik nyonya Satun dan tuan Ngatimir menjadi PPJB bertingkat satu.

\section{Metode Penelitian}

Tipe penelitian dalam penelitian ini menggunakan tipe penelitian hukum yuridis normatif yang mana penelitian hukum yuridis normatif didasarkan pada 
studi kepustakaan yang meliputi bahan hukum primer dan bahan hukum sekunder yang terdiri dari peraturan perundang-undangan dan literatur terkait dengan penelitian ini. ${ }^{3}$ Metode penelitian ini disamping melihat dari aspek hukum positif tetapi juga melihat penerapannya dalam yang ada dalam masyarakat. Penelitian ini menggunakan pendekatan undang-undang (statute approach) merupakan ysng digunakan untuk menelaah semua undang-undang beserta regulasi yang berkaitan dengan isu hukum dalam penelitian ini $^{4}$ dan pendekatan konseptual (conceptual approach) yang beranjak dari pandangan-pandangan dan doktrindoktrin yang berkembang di dalam ilmu hukum. ${ }^{5}$

\section{Konsep Jual Beli Tanah Dalam Hukum Tanah Atas Akta Perjanjian Pengikatan Jual Beli Bertingkat Yang Dibuat Oleh Notaris}

Menurut Adrian Sutedi bahwa jual beli tanah dalam hukum adat mempunyai pengertian yang sama dengan jual beli yang ada pada Pasal 5 Undang-Undang Nomor 5 Tahun 1960 Tentang Peraturan Dasar Pokok-Pokok Agraria yang selanjutnya disebut UUPA. ${ }^{6}$ Pasal 5 UUPA mengatur bahwa hukum agrarian ialah hukum adat, dalam hukum adat suatu jual beli harus memenuhi tiga asas yaitu asas terang, tunai dan riil. Adanya syarat asas terang dan tunai ini mengakibatkan jual beli tidak dapat dibatalkan, karena jual beli ini bukan merupakan perjanjian melainkan perbuataan hukum yang mana perbuatan hukum tersebut merupakan pemindahan penguasaan atas tanah yang mana pemindahan tersebut secara langsung dan riil. ${ }^{7}$

1. Tahapan jual beli tanah

Sebagai pembeli dalam jual beli tanah, pembeli harus mengetahui tahapantahapan dalam jual beli tanah.

\footnotetext{
${ }^{3}$ Soerjono Soekanto dan Sri Mamudji, Penelitian Hukum Normatif Suatu Tinjauan Singkat (Raja Grafindo Persada 2006).[13-14].

${ }^{4}$ Peter Mahmud Marzuki, Penelitian Hukum (Kencana Prenada Media Group2011.[93].

${ }^{5}$ ibid.[95].

${ }^{6}$ Adrian Sutedi, Peralihan Hak Atas Tanah dan Pendaftarannya (Sinar Grafika 2010).[149].

${ }^{7}$ Nur Hayati, ‘Peralihan Hak Dalam Jual Beli Hcak Atas Tanah (Suatu Tinjauan terhadap Perjanjian Jual Beli dalam Konsep Hukum Barat dan Hukum Adat dalam Kerangka Hukum Tanah Nasional)' (2016) 13 Lex Jurnalica.[284].
} 
a. Memenuhi syarat materiil

Syarat materiil ini berhubungan dengan subyek pemegang hak atas tanah apakah penjual adalah benar-benar pemilik dari tanah dan pembeli apakah berhak atas hak atas tanah yang jual tersebut. Tentunya penjual dan pembeli harus sama-sama cakap dalam hukum, tidak hanya dewasa namun arti cakap adalah penjual adalah orang yang berhak untuk menjual tanahnya. Penjual dan pembeli harus menyiapkan dokumen seperti:

1. Sertipikat hak atas tanah, jika tanah belum didaftrakan maka dapat berupa bukti hak lama yang terdapat di penjelasan Pasal 24 ayat (1) PP 24/1997 dan dokumen-dokumen pelengkap seperti peta bidang dan lain sebagainya;

2. Kartu tanda penduduk (KTP) dan kartu keluarga (KK);

3. Surat nikah jika penjual sudah memiliki pasangan kawin;

4. Nomor pokok wajib pajak (NPWP);

5. Surat pemberitahuan pajak tanah dan bangunan;

6. Jika tanah berupa tanah waris harus ada surat keterangan kematian dan surat keterangan waris.

b. Memenuhi syarat formil

Syarat ini berkaitan dengan pendaftaran tanah, dalam jual beli tanah harus dibuktikan dengan menggunakan akta yang dibuat oleh PPAT sebagaimana diatur dalam Pasal 37 ayat (1) PP 24/1997 jual beli dibuktikan dengan akta yang dibuat oleh PPAT, akta ini nantinya sebagai bukti bahwa tanah sudah berpindah dari penjual ke pembeli. Akta yang dibuat oleh PPAT ini harus ada dua saksi yang menyaksikan penandatangan akta. Akta yang dibuat oleh PPAT harus rangkap empat yang mana satunya disimpan oleh PPAT sebagai dokumen negara yang dititipkan ke PPAT, yang satunya digunakan untuk mendaftarkan hak atas tanahnya untuk proses balik nama, dan untuk penjual dan pembeli.

Jika dikaitkan dengan kasus dalam penelitian ini, obyek tanah jual beli ini belum didaftarkan ke Kantor Pertanahan Kabupaten/Kota. Tanah masih berupa bukti hak lama yang terdapat dalam penjelasan Pasal 24 ayat (1) huruf e PP 24/1997 yaitu Surat Keputusan Gubernur Kepala Daerah Tingkat I Jawa Timur Nomor I/ Agr/117/XI/HM/01.G/1970 tertanggal 4 Nopember tahun 1970 
atau SK Gubernur. Tuan Sarbilin, nyonya Demi, tuan Soeradi, tuan Suwardi, tuan MAA dan tuan Samsu merupakan subyek hukum yang sudah cakap dalam melakukan perbuatan hukum jual beli cakap dalam hal ini dewasa. Seharusnya setelah adanya akta PPJB ditahun 1994, 1997 dan 2012 tanah yang berdasarkan SK Gubernur tersebut didaftarkan.

2. Pendaftaran Tanah

Pendaftaran tanah ini diselenggarakan untuk memberikan jaminan kepastian hukum dalam bidang pertanahan, yang nantinya akan menghasilkan surat-surat tanda bukti hak yang berlaku sebagai alat pembuktian yang kuat. ${ }^{8}$ Pendaftaran tanah ini dilaksanakan dengan dua cara yaitu pendaftaran tanah secara sistematik dan sporadik. Secara sistematik ini biasanya adanya program dari pemerintah untuk mendaftarakan tanah secara massal, sedangan sporadik ini merupakan pendaftaran tanah secara individu atau massal atas inisitif dari individunya sendiri. Pendaftaran tanah saat ini diatur dalam PP 24/1997 sebelum berlakunya PP 24/1997, pendaftaran tanah diatur dalam PP 10/1961. Menurut Urip Santoso Peraturan Pemerintah No. 24 Tahun 1997 disamping mencabut juga menyempurnakan substansi Peraturan Pemerintah No. 10 Tahun 1961. ${ }^{9}$ Obyek tanah dalam penelitian ini merupakan tanah yang belum bersertipikat maka prosedur dalam pendaftaranya adalah sebagai berikut: ${ }^{10}$

a. Pengumpulan Data Fisik

Pengumpulan data fisik ini bertujuan untuk mengetahui batas-batas, letak serta luas dari tanah dan juga apakah diatas tanah tersebut terdapat bangunan atau tidak. Petugas dari kantor pertanahan harus datang ke lokasi untuk pemasangan batas-batas, pemasangan batas-batas ini harus mendapatkan persetujuan dari para pemegang hak atas tanah sekitar obyek tanah yang akan dipasangin batas-batas.

b. Pengumpulan Data Yuridis

Setelah dilakukannya pengukuran yang dituangkan dalam peta bidang, maka dilanjutkan dengan mengumpulkan dan meneliti kebenaran dari alat-alat

\footnotetext{
${ }^{8}$ Urip Santoso, Pendaftaran dan Peralihan Hak Atas Tanah (Prenadamedia Group 2010).[7].

${ }^{9}$ ibid.[5].

${ }^{10}$ Suparjo Sujadi, 'Pendaftaran Tanah (Initial Registration) Tanah Bekas Milik Adat Di Kantor Pertanahan Kabupaten Bogor dan Kota Depok (Laporan Penelitian Singkat Mengenai Praktek Pelaksanaanya)' (2014), 2 Hukum dan Pembangunan.[147].
} 
bukti yang diajukan oleh pemegang hak hal ini bertujuan untuk memperoleh data yuridis sebagaimana diatur dalam Pasal 25 PP 24/1997. Data yuridis ini berisikan tentang siapa pemegang haknya dan status tanah.

c. Pengumuman

Jika sebagaimana dalam Pasal 25 PP 24/1997 sudah terlaksana, maka dalam Pasal 26 PP 24/1997 mengatur untuk mengumumkan daftar isian yang berisi data yuridis dan data fisik serta peta bidang tanah.

d. Penegasan Konversi

Penegasan konversi ini terjadi jika alat-alat bukti lengkap. Penegasan konversi ini dilakukan oleh Kepala Kantor Pertanahan dengan menambah catatan dalam risalah hasil penelitian dan penetapan batas tentang penegasan konversi hak atas tanah tersebut menjadi hak milik yang mencantumkan nama pemohon sebagai pemegang hak. ${ }^{11}$

e. Pembukuan Hak

Pembukuan hak ini sebagaimana diatur dalam Pasal 29 ayat (1) PP 24/1997 dengan membuat buku tanah. Buku tanah memuat data yuridis dan data fisik.

f. Penerbitan Sertipikat

Jika dalam buku tanah sudah lengkap dan tidak ada catatan kekurangan data fisik maupun data yuridis dan tidak ada sengketa yang terjadi maka sertipikat dapat diterbitkan sebagaimana diatur dalam Pasal 31 PP 24/1997. Sertipikat yang telah terbit hanya boleh diserahkan kepada pihak yang namanya tercantum dalam buku tanah.

Jika tahap-tahap sebagaimana diatas telah dilakukan dan hak milik atas tanah berdasarkan SK Gubernur telah menjadi sertipikat maka selanjutnya bisa dilakukan penandatangan akta jual beli yang dibuat oleh PPAT. Kasus dalam penelitian ini seharusnya setelah adanya akta PPJB maka melakukan pendaftaran tanah seperti uraian diatas setelah adanya sertipikat maka dapat dilaksanakannya pendandatangan AJB. Para subyek jual beli dikasus ini tidak melaksanakan apa yang seharusnya, tetapi para subyek jual beli malah mengikat kembali dengan akta PPJB dan akta kuasa, dengan premis menyatakan bahwa pihak pembeli merupakan pemilik obyek tanah berdasarkan akta PPJB dan akta kuasa, padahal akta PPJB bukan merupakan bukti kepemilikan tanah, sehingga mengkibatkan PPJB bertingkat. Perbedaan Akta Pengikatan Jual Beli Bertingkat dengan Akta Perjanjian Pengikatan biasa.

${ }^{11}$ ibid.[148]. 


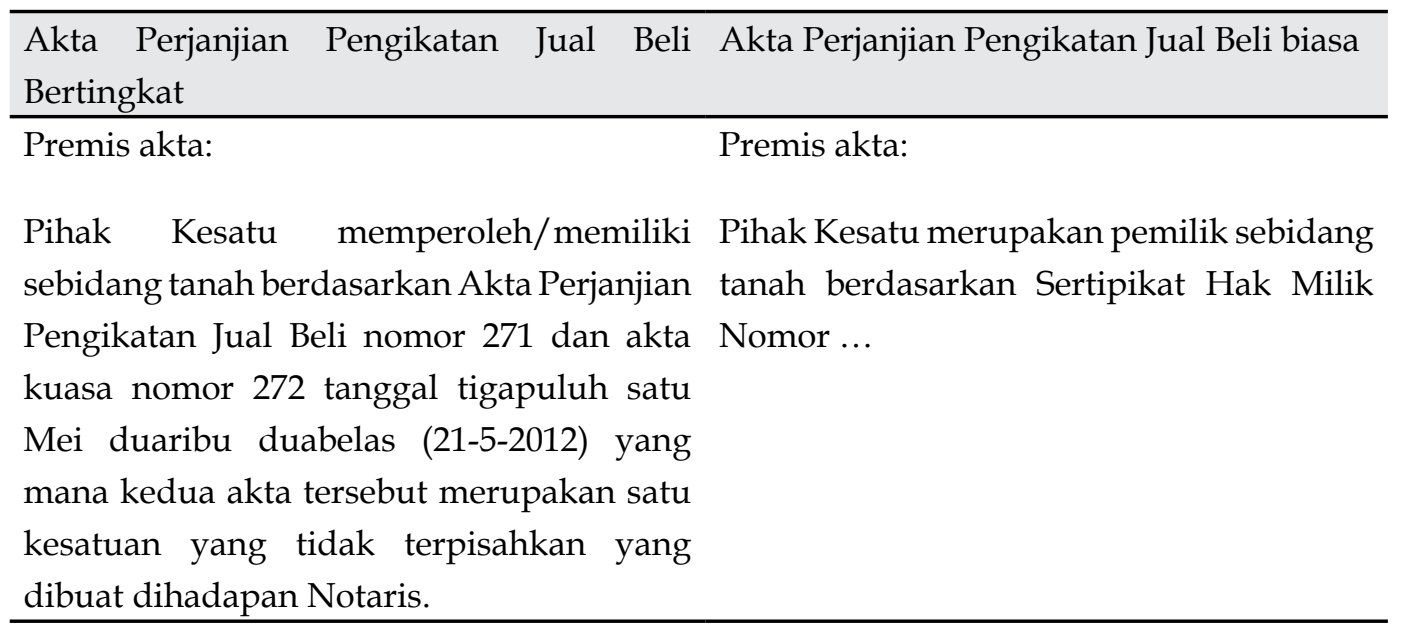

Selain dalam kasus ini akta kuasa memakai akta kuasa mutlak. Perlu diperhatikan bahwa suatu akta kuasa tidak boleh mutlak hal tersebut dilarang penggunaanya diatur dalam Instruksi Menteri Dalam Negeri Nomor 14 Tahun 1982 Tentang Larangan Penggunaan Surat Kuasa Mutlak Sebagai Pemindahan Hak Atas Tanah. Kuasa mutlak adalah kuasa yang diberikan kepada penerima kuasa selaku pembeli yang mana kuasa tersebut telah melampaui kewenangan yang diberikan oleh si pemberi kuasa yaitu penjual. Menurut diktum kedua Instruksi Menteri Dalam Negeri Nomor 14 Tahun 1982 Tentang Larangan Penggunaan Surat Kuasa Mutlak Sebagai Pemindahan Hak Atas Tanah bahwa kuasa mutlak memiliki 3 unsur:

1. Objek kuasa tersebut adalah tanah;

2. Kuasa tersebut mengandung unsur tidak dapat ditarik kembali;

3. Kuasa tersebut memberikan kewenangan kepada penerima kuasa untuk melakukan perbuatan hukum yang menurut hukum perbuatan tersebut hanya dapat dilakukan oleh pemegang haknya saja yang pada hakikatnya melakukan pemindahan hak atas tanah yang dimana si penerima kuasa seolah-olah bertindak sebagai pemegang haka tau pemilik.

Akta PPJB bertingkat sering kali dianggap hal biasa nyatanya dalam teori hal tersebut tidak diperbolehkan. Dalam prakteknya masih ada Notaris yang mau membuatkan akta PPJB bertingkat yang mana dalam premisnya disebutkan bahwa pihak pertama merupakan pemilik tanah berdasarkan akta PPJB dan akta Kuasa. Bukti hak atas tanah adalah sertipikat bukan akta PPJB dan akta kuasa. Belum ada peralihan hak 
atas tanah namun sudah dijual kembali kepada pihak ketiga sehingga terjadi akta PPJB bertingkat. Dalam konsep jual beli tanah dalam hukum tanah jual beli harus memenuhi tiga asas. Asas terang artinya bahwa perbuatan hukum jual beli harus dilakukan dihadapan pejabat yang berwenang. pejabat yang berwenang dalam hal ini adalah PPAT untuk akta PPJB tahun 2015 dan 2015 menurut PP 24 1997, sedangkan untuk akta PPJB tahun 1994 dan 1997 juga belum diadakan jual beli dihadapan kepala desa sesuai yang diatur dalam PP 24/1997. Dalam kasus Notaris bukan pejabat yang berwenang untuk membuat akta jual beli, Notaris berwenang untuk membuat akta PPJB, asas kedua adalah asas tunai yang mana pembayaran dan penyerahan dilakukan bersamaan jika melihat dalam kasus memang terjadi pembayaran lunas terhadap obyek jual beli, namun dalam hal ini belum ada penandatangan akta jual beli, karna memang bentuk penyerahan dari jual beli tanah ini dengan adanya akta jual beli yang kemudian diproses untuk balik nama atas nama pembeli yang kemudian sertipikat nanti tentunya atas nama pembeli. Menurut Urip Santoso dengan telah dibuatnya akta jual beli ini, maka pada saat itu telah terjadi pemindahan hak dari pemegang hak sebagai penjual kepada pihak lain sebagai pembeli. Kasus dalam penelitian ini dari akta PPJB antara pemegang hak yaitu tuan Sarbilin, tuan Soeradi hingga dibeli oleh tuan Samsu dari tuan MAA belum pernah diadakannya penandatangan akta jual beli, sama halnya dengan tanah yang pemiliknya tuan Ngatamir dan nyonya Satun yang kemudian dibeli oleh tuan MAA dan dijual kembali oleh tuan MAA kepada tuan Samsu. Asas yang terakhir adalah asas riil yang memiliki arti bahwa adanya kesepakatan antara para pihak dan juga adanya perbuatan nyata seperti pembayaran yang dilakukan pembeli kepada penjual. Jika dikaitkan dengan kasus yang telah diurakan diatas memang para pihak bersepakat untuk melakukan jual beli atas empat bidang tanah tersebut dan juga adanya pembayaran lunas di akta PPJB 2015 belum ada pelunasan selain itu juga belum adanya peyerahan secara nyata dari penjual ke pembeli. Asas terang dan tunai tidak terpenuhi. Tidak terpenuhinya asas-asas dalam konsep jual beli tanah dalam hukum tanah, maka hal tersebut membuat akta PPJB bertingkat yang dibuat oleh Notaris bertentangan dengan konsep jual beli tanah dalam hukum tanah. 


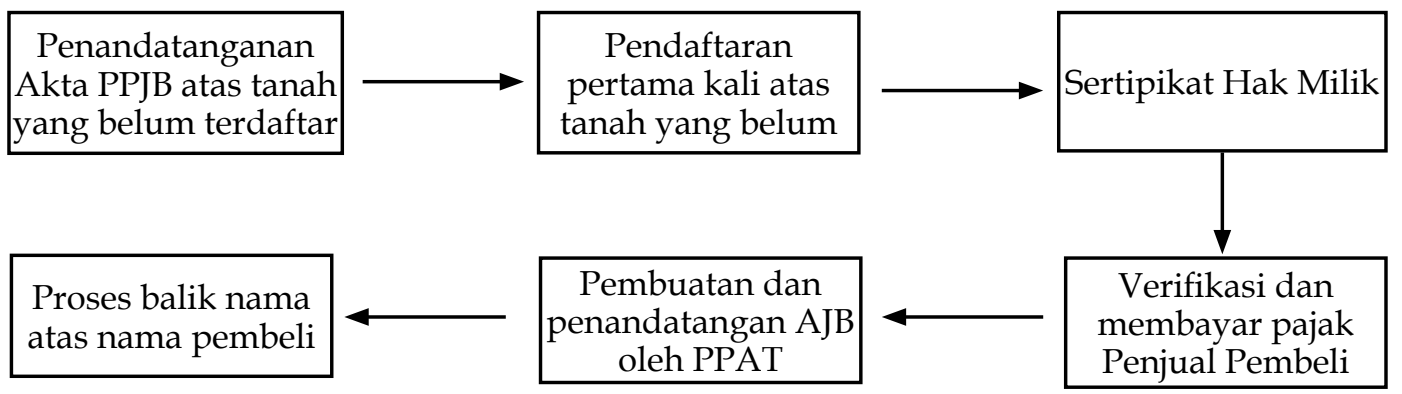

Akibat Hukum Jika Pejabat Pembuat Akta Tanah Menggunakan Dasar Akta Perjanjian Pengikatan Jual Beli Bertingkat Yang Dibuat Oleh Notaris Dalam

\section{Akta Jual Belinya}

1. Akibat Hukum Terhadap Akta Perjanjian Pengikatan Jual Beli Bertingkat Yang Dibuat Oleh Notaris

Sebagaimana yang diatur dalam Pasal 37 PP 24/1997 mengatur bahwa pembuktian adanya jual beli yaitu dengan akta yang dibuat oleh PPAT, bukan akta yang dibuat oleh Notaris. AJB dapat dilaksanakan apabila akta PPJB yang dibuat oleh Notaris telah terpenuhi, jika belum terpenuhi maka AJB pun tidak dapat dilaksanakan. Akta PPJB adalah akta yang berisikan kesepakatan antara penjual dan calon pembeli yang mana penjual dan calon pembeli menyetujui bahwa hak milik atas obyek jual beli akan berpindah kepada calon pembeli pada suatu waktu. ${ }^{12}$ Akibat dari adanya akta PPJB tersebut bukan beralihnya hak milik dari penjual dan calon pembeli namun akibatnya adalah lahirnya perikatan antara penjual dan calon pembeli. Seperti yang telah diuraikan di atas bahwa akta PPJB bukan bukti peralihan hak atas tanah, namun dalam prakteknya akta PPJB dapat di PPJB kan kembali, yang mana akta PPJB tersebut menjadi akta PPJB bertingkat. Akta PPJB bertingkat tidak sesuai dengan teori, akta PPJB bertentangan dengan konsep jual beli tanah dalam hukum tanah, yang mana tidak sesuai dengan asas terang, tunai dan riil.

Akta PPJB dalam melakukan perjanjian pendahuluan yang tunduk dengan Pasal 1320 Burgerlijk Wetboek yang selanjutnya disebut BW. Pasal 1320

${ }^{12}$ Abdul Kadir Muhammad, Hukum Perjanjian (Alumni 1980).[243]. 
mengatur bahwa syarat sah suatu perjanjian adanya suatu kesepakatan antara para pihak, cakap hukum, suatu hal tertentu dan suatu hal yang diperbolehkan. Jika tidak memenuhi kesepatan dan cakap dalam hukum artinya tidak memenuhi syarat subyektif dapat mengakibatkan dapat dibatalkanya suatu perjanjian. Jika tidak memenuhi syarat obyektif yaitu suatu hal tertentu dan suatu hal yang diperbolehkan maka batal demi hukum. Jika dilihat kasus dalam penelitian ini yaitu syarat sah suatu perjanjian:

1. Adanya suatu kesepakatan. Para pihak dalam kasus tersebut sepakat untuk melakukan perbuatan hukum jual beli dengan pembayaran lunas. Para pihak juga sepakat untuk menandatangani akta PPJB dan akta kuasa yang dibuat oleh Notaris.

2. Cakap hukum

Orang yang dapat melakukan perbuatan hukum harus sudah dewasa, dewasa menurut Pasal 330 BW adalah ia yang berumur 21 tahun, sedangkan Menurut Pasal 39 ayat (1) Undang-Undang Nomor 2 Tahun 2014 Tentang Perubahan Undang-Undang Nomor 30 Tahun 2004 Tentang Jabatan Notaris mengatur yang boleh membuat perjanjian atau yang dapat menghadap Notaris adalah ia yang berusia 18 tahun. Selain itu orang yang cakap hukum bukan orang yang berada dibawah pengampuan. Jika dikaitkan dalam kasus memang para pihak ini sudah dewasa umur para pihak sudah cakap hukum, namun dalam hal ini cakap hukum tidak hanya tentang dewasa dan tidak dibawah pengampu, tetapi cakap hukum memiliki arti bahwa penjual benar-benar orang yang berhak untuk menjual tanah. Akta PPJB bertingkat belum ada peralihan hak atas tanah namun obyek tanah dijual dengan dasar kepemilikan akta PPJB. Nyonya Demi, tuan Suwardi jika menjual kepada tuan MAA maka termasuk orang yang tidak cakap, karena nyonya demi dan tuan suwardi bukan orang yang berhak untuk menjual obyek hak atas tersebut kepada tuan MAA. Obyek jual beli tersebut belum beralih ke tuan Suwardi dan nyonya Demi, tuan MAA juga merupakan orang yang tidak cakap hukum karena belum ada 
peralihan hak atas tanah namun sudah dijual dan memPPJBkan akta PPJB sebelumnya ke tuan Samsu.

Jika dikaitkan dengan pembeli beritikad baik, Menurut Sogar Simamora itikad baik memiliki dua makna yang mana makna yang pertama itikad baik diartikan perilaku yang patut dan layak antar kedua pihak. Kedua itikad baik memiliki makna sebagai keadaan yang tidak mengetahui adanya cacat. ${ }^{13}$ Pembeli beritikad baik menurut Pasal 1338 ayat (3) BW mengatur bahwa suatu perjanjian haruslah dilaksanakan dengan itikad baik, Itikad baik ini disebut dengan kepatutan. Dalam melaksanakan perjanjian dengan itikad baik memilik arti bahwa harus sesuai dengan norma-norma kepatutan dan kesusilaan yang ada dalam masyarakat. Dalam kasus bahwa tuan MAA mengetahui bahwa belum ada peralihan hak atas tanah, begitupun tuan Samsu juga mengatahui bahwa tanah belum menjadi hak milik tuan MAA.

Jika dikaitkan dengan itikad baik menurut Surat Edaran Nomor 4 Tahun 2016 Tentang Pemberlakuan Rumusan Hasil Rapat Pleno Kamar Mahkamah Agung Tahun 2016 Sebagai Pedoman Pelaksanaan Tugas Bagi Pengadilan yang selanjutnya disebut dengan SEMA nomor 4 tahun 2016 dalam Rumusan Hukum Kamar Perdata Umum nomor 7 mengatur tentang jika peralihan hak atas tanah berdasarkan akta PPJB yang mana pembelinya membayar lunas harga tanah maka telah menguasai objek jual beli dan dilakukan dengan itikad baik. Pembeli dikatakan sebagai pembeli beritikad baik dan juga perlu dilindungi berdasarkan Pasal 1338 ayat (3) BW apabila pembelian tanah tersebut melalui pelelangan umum, pembelian tanah sesuai dengan PP 24/1997 yaitu dihadapan PPAT, selain itu untuk tanah yang belum bersertipikat maka pembeliannya dilakukan menurut ketentuan adat yaitu dihadapan kepala desa atau lurah dimana tanah tersebut berada jual beli tersebut harus sesuai dengan asas terang

\footnotetext{
${ }^{13}$ Sogar Simamora, Hukum Kontrak Prinsip-Prinsip Hukum Kontrak Pengadaan Barang dan Jasa Pemerintah di Indonesia (Laskbang Pressindo 2017).[34].
} 
dan tunai. Tidak hanya itu sebelum diadakannya jual beli dihadapan kepala desa atau lurah harus dilakukan penelitian terlebih dahulu guna memastikan tanah tersebut merupakan tanah penjual dan pembelian dilakukan dengan harga yang layak. Selain harus sesuai dengan peraturan perundang-undangan pembeli juga harus menerapkan prinsip kehatihatian yang mana prinsip tersebut meneliti hal-hal yang berkaitan dengan objek tanah. Meneliti bahwa penjual merupakan pemilik sebenarnya orang yang berhak untuk menjual tanah dengan bukti yang sah, tanah tidak dalam sengketa tidak dalam status dijaminkan, untuk tanah yang sudah bersertipikat pembeli harus memastikan ke Kantor Pertanahan Kabupaten/Kota. Sama halnya dengan pendapat Urip Santoso yang merujuk pada Arie S. Hutagalung yang mana seorang calon pembeli dikatakan beritikad baik apabila sebelum melakukan jual beli tanah maka harus meneliti keabsahan dari pemilik tersebut. ${ }^{14}$ pembeli yang beritikad baik adalah pembeli yang dilindungi oleh undang-undang.

Tuan MAA dan tuan Samsu dapat dikatakan bahwa tuan MAA dan tuan Samsu merupakan pembeli yang tidak beritikad baik. Tuan MAA dan tuan Samsu mengetahui bahwa tanah tersebut belum menjadi hak milik nyonya Demi dan tuan Suwardi dan bukan pula milik tuan MAA. Maka jika ada sengketa maka tuan MAA dan tuan Samsu tidak mendapatkan perlindungan dari undang-undang.

3. Suatu hal tertentu

Suatu hal tertentu ini adalah suatu hal yang jelas suatu hal yang dapat dijual suatu hal yang dapat dihitung. Dalam kasus obyek hak atas tanah berupak SK Gubernur. SK Gubernur ini merupakan tanah yang belum didaftarkan belum ada sertipikatnya. SK Gubernur ini termasuk dalam Keputusan Tata Usaha Negara (KTUN). Dilihat dari pengertian KTUN menurut Pasal Undang-Undang Nomor 51 Tahun 2009 Tentang 
Perubahan Kedua atas Undang-Undang Nomor 5 Tahun 1986 Tentang Peradilan Tata Usaha Negara pada Pasal 1 angka 9 bahwa KTUN adalah suatu penetapan tertulis yang mana penetapan tersebut dikeluarkan oleh badan atau pejabat tata usaha negara yang mana berisikan tindakan hukum tata usaha negara yang berdasarkan peraturan perundang-undang yang berlaku, bersifat konkret, individual dan final, yang dapat menimbulkan akibat hukum bagi seseorang. Dikaitkan dengan SK Gubernur tersebut bersifat konkret dalam hal ini suatu keputusan harus jelas, tertentu atau dapat ditentukan dan juga berwujud serta tidak abstrak. Keputusan yang ada dalam SK Gubernur ini jelas yaitu memberikan hak milik atas hak pakai bekas hak gogolan tidak tetap. SK Gubernur juga tidak ditujukan untuk umum, SK Gubernur ini ditujukan untuk orang-orang yang mendapatkan hak miliknya berdasarkan hak gogolan tidak tetap. Bersifat final ini maksudnya adalah suatu keputusan itu menimbulkan akibat hukum, sama halnya dengan SK Gubernur yang menimbulkan akibat hukum bagi mereka yang diberikan hak milik tersebut, selain itu SK Gubernur tersebut sudah berlaku tanpa harus menunggu persetujuan pejabat lainnya. ${ }^{15} \mathrm{SK}$ Gubernur tersebut juga tidak termasuk dalam keputusan yang ada dalam Pasal 2 Undang-Undang Nomor 9 Tahun 2004 Tentang Perubahan atas Undang-Undang Nomor 5 Tahun 1986 Tentang Peradilan Tata Usaha Negara. Kesimpulannya bahwa SK Gubernur yang memberikan hak milik atas tanah hak pakai hak gogolan tidak tetap tersebut termasuk dalam keputusan tata usaha negara. Sebagaimana Pasal 1 angka 9 UndangUndang Nomor 51 Tahun 2009 Tentang Perubahan Kedua atas UndangUndang Nomor 5 Tahun 1986 Tentang Peradilan Tata Usaha. Dalam SK Gubernut juga dinyatakan bahwa SK Gubernut harus didaftarkan ke Kantor Pertanahan Kabupaten/Kota.

4. Suatu hal yang diperbolehkan 
Suatu hal yang diperbolehkan ini memiliki arti suatu perjanjian obyeknya adalah hal yang tidak dilarang oleh undang-undang, tidak dilarang oleh masyarakat pada umumnya. Dalam kasus ini obyeknya berupa tanah. Tanah merupakan obyek perjanjian yang diperbolehkan tidak dilarang oleh undang-undang.

Jika dilihat dalam uraian diatas akta PPJB bertingkat ini memenuhi syarat sah perjanjian yang pertama yaitu kesepakatan para pihak, selain itu yang diperjanjian adalah hal yang diperbolehkan yaitu tanah suatu hal yang tidak dilarang. Suatu hal tertentu dalam hal ini tanah termasuk obyek yang dapat dihitung dan jelas, sehingga sudah memenuhi syarat obyektif. Ada syarat dari syarat subyektif yang tidak dipenuhi yaitu cakapnya para pihak, tuan Suwardi, nyonya Demi, tuan MAA dan tuan Samsu bukan orang yang berhak untuk menjual tanah hak milik berdasarkan SK Gubernur, maka akibat hukumnya adalah dapat dibatalkan.

2. Akibat Hukum Atas Akta Jual Beli Yang Dibuat Berdasarkan Akta Perjanjian Pengikatan Jual Beli Bertingkat

Akta jual beli atau bisa disebut dengan AJB adalah akta otentik yang dibuat oleh PPAT. Akta jual beli ini digunakan sebagai bukti bahwa ada perbuatan hukum peralihan hak atas tanah. Berbeda dengan akta PPJB yang jika dilakukan penandatangan belum terjadi peralihan hak atas tanah, dengan dilakukannya penandatangan AJB ini maka peralihan hak atas tanah telah terjadi, yang selanjutnya AJB ini nanti akan didaftakan ke Kantor Pertanahan Kabupaten/Kota untuk proses balik nama. Menurut Urip Santoso dengan dibuatkannya AJB tersebut oleh PPAT maka saat itu telah terjadi pemindahan hak atas tanah dari penjual ke pembeli. Tidak serta merta setelah adanya AJB kepemilikan berpindah begitu saja, namun perlu adanya pendaftaran tanah. Hal tersebut agar pihak ketiga mengetahui adanya jual beli tanah tersebut, maka terpenuhilah asas publisitas. Asas Publisitas ini ditujukan untuk pihak ketiga selain mengatahui adanya jual beli tanah tapi pihak ketiga juga dapat mengetahui data fisik dan data 
yuridis di Kantor Pertanahan Kabupaten/Kota. ${ }^{16}$ Pada umumnya jika AJB dibuat berdasarkan akta PPJB maka akta PPJB dan akta kuasa tersebut nantinya juga kan disertakan dalam proses balik nama sertipikat atau dalam pendaftaran hak atas tanah.

Di dalam AJB nantinya akan ditambahkan klausul bahwa AJB dibuat berdasarkan akta PPJB dan akta Kuasa. Akta PPJB bertingkat tidak diperbolehkan, Kantor Pertanahan Kabupaten/Kota pun juga tidak memperbolehkan adanya akta PPJB bertingkat. ${ }^{17}$ karena sesuai dengan Pasal 37 ayat (1) PP 24/1997 bahwa bukti adanya peralihan hak atas tanah adalah akta yang dibuat oleh PPAT bukan akta yang dibuat oleh Notaris. Prakteknya masih ada akta PPJB bertingkat dan akta kuasa mutlak, hal ini menyebabkan tidak adanya kepastian hukum, sehingga jika AJB dibuat berdasarkan akta PPJB bertingkat dan akta kuasa mutlak hal ini dapat mengakibatkan batal demi hukum suatu AJB karena kuasa mutlak ini merupakan causa yang tidak dipebolehkan. Sebagaimana diatur dalam Pasal 39 ayat (1) huruf d PP 24/1997 bahwa PPAT harus menolak membuat AJB atas dasar kuasa mutlak. Selain diatur dalam Pasal 39 ayat (1) huruf d PP 24/1997, larangan kuasa mutlak juga diatur dalam Instruksi Menteri Dalam Negeri Nomor 14 tahun 1982 Tentang Larangan Penggunaan Kuasa Mutlak Sebagai Pemindahan Hak Atas Tanah. Jika PPAT tetap membuatkan AJB berdasarkan akta kuasa mutlak maka PPAT dapat dikenakan sanksi. Sanksi tersebut merupakan sanksi administrasi sebagaimana diatur dalam Pasal 62 PP 24/1997 yaitu berupa teguran tertulis sampai pemberhentian dari jabatannya. Akta kuasa mutlak ini selalu bertalian dengan akta PPJB yang bertingkat. Batal demi hukum suatu akta jual beli maka dianggap tidak ada perbuatan hukum sejak awal.

\footnotetext{
${ }^{16}$ Urip Santoso I, Op.Cit.[371-372].

${ }^{17}$ Leny Kurniawati, 'Akta Perjanjian Pengikatan Jual Beli dan Kuasa Menjual Sebagai Bentuk Perlindungan Hukum Terhadap Pembeli Hak Atas Tanah' (2018) 2 Jurnal Hukum dan Kenotariatan. [16].
} 


\section{Kesimpulan}

Akta PPJB merupakan akta pendahuluan yang dibuat karena tanah belum bersertipikat. AJB dilaksanakan jika syarat-syarat yang ada pada akta PPJB telah terpenuhi seluruhnya. Akta PPJB harusnya hanya sekali saja, namun prakteknya ini masih ada akta PPJB bertingkat atau akta PPJB berulang. Akta PPJB bertingkat tidak sesuai dengan asas terang dan tunai serta tidak sesuai dengan PP 24/1997 oleh karena itu akta PPJB bertentangan dengan asas jual beli dalam hukum tanah.

Akta PPJB lunas menyebabkan pembeli dapat menguasai obyek dengan itikad baik, pembeli dapat dikatakan sebagai itikad baik apabila dalam melakukan jual beli harus sesuai dengan peraturan perundang-undangan dan juga melakukan kehati-hatian. Akta PPJB bertingkat dapat dikatakan sebagai pembeli yang tidak beritikad baik dan tidak cakapnya hukum yang mengakibatkan dapat dibatalkannya akta PPJB bertingkat dan akta kuasa mutlak, sehingga jika akta jual beli dibuat berdasarkan akta PPJB bertingkat dan kuasa mutlak maka akta tersebut batal demi hukum, yang dianggap sejak awal tidak ada pebuatan peralihan hak atas tanah. Kanto Pertanahan Kabupaten/Kota juga melarang adanya akta PPJB bertingkat.

\section{Daftar Bacaan}

\section{Buku}

Abdul Kadir Muhammad, Hukum Perjanjian (Alumni 1980).

Adrian Sutedi, Peralihan Hak Atas Tanah dan Pendaftarannya (Sinar Grafika2010).

Maria S. W. Sumarjono, Kebijakan Pertanahan antara Regulasi dan Implementasi (Buku Kompas 2001).

Peter Mahmud Marzuki, Penelitian Hukum (Kencana Prenada Media Group 2011).

R. Subekti, Hukum Perjanjian (Bina Cipta 1987).

Soerjono Soekanto dan Sri Mamudji, Penelitian Hukum Normatif Suatu Tinjauan Singkat (Raja Grafindo Persada 2006).

Sogar Simamora, Hukum Kontrak Prinsip-Prinsip Hukum Kontrak Pengadaan Barang 
234 | Nailu Vina: Jual Beli Tanah...

dan Jasa Pemerintah di Indonesia (Laskbang Pressindo 2017).

Supatra Nata, Hukum Administrasi Negara (Rajawali 1988).

Urip Santoso, Pendaftaran dan Peralihan Hak Atas Tanah (Prenadamedia Group 2010).

, Perolehan Hak Atas Tanah (Prenadamedia Group 2015).

\section{Jurnal}

Leny Kurniawati, 'Akta Perjanjian Pengikatan Jual Beli dan Kuasa Menjual Sebagai Bentuk Perlindungan Hukum Terhadap Pembeli Hak Atas Tanah' (2018) 2 Jurnal Hukum dan Kenotariatan.

Nur Hayati, 'Peralihan Hak Dalam Jual Beli Hcak Atas Tanah (Suatu Tinjauan terhadap Perjanjian Jual Beli dalam Konsep Hukum Barat dan Hukum Adat dalam Kerangka Hukum Tanah Nasional)' (2016) 13 Lex Jurnalica.

Suparjo Sujadi, 'Pendaftaran Tanah (Initial Registration) Tanah Bekas Milik Adat Di Kantor Pertanahan Kabupaten Bogor dan Kota Depok (Laporan Penelitian Singkat Mengenai Praktek Pelaksanaanya)' (2014) 2 Hukum dan Pembangunan.

How to cite: Nailu Vina Amalia, 'Jual Beli Tanah Dalam Hukum Tanah Atas Akta Perjanjian Pengikatan Jual Beli Bertingkat yang Dibuat oleh Notaris' (2021) Vol. 4 No. 2 Notaire. 